TITLE:

\title{
High antioxidant activity of coffee silverskin extracts obtained by the treatment of coffee silverskin with subcritical water.
}

\section{$\operatorname{AUTHOR}(\mathrm{S})$ :}

Narita, Yusaku; Inouye, Kuniyo

\section{CITATION:}

Narita, Yusaku ...[et al]. High antioxidant activity of coffee silverskin extracts obtained by the treatment of coffee silverskin with subcritical water.. Food Chemistry 2012, 135(3): 943-949

ISSUE DATE:

2012-12

URL:

http://hdl.handle.net/2433/160217

\section{RIGHT:}

@ 2012 Elsevier Ltd.; この論文は出版社版でありません。引用の際には 出版社版をご確認ご利用ください。; This is not the published version. Please cite only the published version. 


\section{High Antioxidant Activity of Coffee Silverskin}

$5{ }^{a}$ Division of Food Science and Biotechnology, Graduate School of Agriculture, Kyoto University,

6 Sakyo-ku, Kyoto 606-8502, Japan

$7 \quad{ }^{\mathrm{b}}$ R\&D Center, UCC Ueshima Coffee Co., Ltd., 3-1-4 Zushi, Takatsuki-shi, Osaka 569-0036,

8 Japan

$9 \quad$ AUTHOR EMAIL ADDRESS: inouye@kais.kyoto-u.ac.jp

10 TITLE RUNNING HEAD: Antioxidant capacities of coffee silverskin subcritical water extracts.

11 CORRESPONDING AUTHOR FOOTNOTE:

$12{ }^{*}$ corresponding author. Tel.: +81-75-753-6266. Fax: +81-75-753-6265. E-mail address:

13 inouye@kais.kyoto-u.ac.jp. Postal address: Division of Food Science and Biotechnology,

14 Graduate School of Agriculture, Kyoto University, Sakyo-ku, Kyoto 606-8502, Japan.

$15{ }^{\mathrm{a}}$ Kyoto University.

$16{ }^{\mathrm{b}} \mathrm{UCC}$ Ueshima Coffee Co., Ltd.. 
18 Abstract

19 Coffee silverskin (CS) is a thin tegument of the outer layer of green coffee beans and a major

20 by-product of the roasting process to produce roasted coffee beans. CS extracts obtained by the

21 treatment of CS with subcritical water at $25-270{ }^{\circ} \mathrm{C}$ were investigated on their antioxidant

22 activity using hydrophilic oxygen radical absorption capacity (H-ORAC) and DPPH radical

23 scavenging capacity assays. The antioxidant activity increased with increasing the extraction

24 temperature and the highest activity was observed with the extracts obtained at $270{ }^{\circ} \mathrm{C}$. The $\mathrm{H}-$

25 ORAC and DPPH values of the extracts were $2629 \pm 193$ and $379 \pm 36 \mu \mathrm{mol}$ TE/g of CS extract,

26 respectively. High correlation $(R=0.999)$ was observed between H-ORAC and DPPH values for

27 the CS extracts. High correlation of the antioxidant activity was also observed with protein and

28 phenolic contents in the extracts. The CS extracts could be useful as a good source of 29 antioxidative materials.

31 Keywords: Antioxidant; Biomass; Coffee; Coffee silverskin; Subcritical water 
33 1. Introduction

35 Coffee is one of the most consumed popular beverages throughout the world. Coffee silverskin

36 (CS) is a thin tegument of the outer layer of green coffee beans and a major by-product of the

37 roasting process to produce roasted coffee beans. Most CS is disposed of as industrial waste

38 because the effective utilizing of CS has not yet been developed. Therefore CS can be regarded as

39 biomass which is expected to be utilized. Many investigators have reported the physiological

40 functions of green and roasted coffee beans, such as $\alpha$-amylase inhibition (Narita \& Inouye, 2009;

41 Narita \& Inouye, 2011), tyrosinase inhibition (Iwai, Kishimoto, Kakino, Mochida, \& Fujita,

42 2004), and antioxidant activity (Richelle, Tavazzi, \& Offord, 2001), etc. On the other hand, the

43 physiological functions of CS reported until now are antioxidant activity (Borrelli, Esposito,

44 Napolitano, Ritieni, \& Fogliano, 2004), previotic property (Borrelli et al., 2004), and

45 hyaluronidase inhibition (Furusawa, Narita, Iwai, Fukunaga, \& Nakagiri, 2011), but the number

46 of the reports is much less than that for coffee bean.

47 The water maintained in the liquid state by pressurizing in the temperature ranging between

$48 \quad 100$ and $374{ }^{\circ} \mathrm{C}$ is called subcritical water. The specific inductive capacity or dielectric constant

49 of water remarkably lowered with increasing temperature (Miller \& Hawthorne, 1998). The

50 specific inductive capacity of subcritical water in the temperature range of between $200{ }^{\circ} \mathrm{C}$ and

$51300{ }^{\circ} \mathrm{C}$ is comparable as polar organic solvents such as methanol and acetone. Moreover,

52 subcritical water has the characteristic which functions as acid or alkali catalyst, because the ionic

53 product of the subcritical water is higher than water under normal temperature and pressure. From

54 these features, research using subcritical water is advanced especially for treatment of food waste,

55 such as grape seeds, okara (Wakita et al., 2004), wheat bran (Kataoka, Wiboonsirikul, Kimura, \&

56 Adachi, 2008), defatted rice bran (Wiboonsirikul, Kimura, Kadota, Morita, Tsuno, \& Adachi,

57 2007a). It is expected to be environment-friendly to extract active ingredients, such as proteins

58 and carbohydrates, from food waste using subcritical water without using organic solvents and 
59 other catalysts. Furthermore, it is excellent in safety not to use the substances harmful to human at 60 the extraction process.

61 It is well known that the oxidative stress must be a factor to cause various diseases, such as 62 cancer (Lambert \& Yang, 2003), cardiovascular disease (Diaz, Frei, Vita, \& Keaney, 1997), type 632 diabetes (Takayanagi, Inoguchi, \& Ohnaka, 2011), Alzheimer's disease (Christen, 2000), and 64 Parkinson's disease (Lang \& Lozano, 1998). Antioxidants exhibit important effects for human 65 health by reducing oxidative stress, and also are used to prevent food from discoloring and changing flavor. Therefore, antioxidants have recently attracted attention against oxidative stress. Antioxidants are divided roughly into natural and synthesized products. Consumers generally prefer natural antioxidants to synthetic ones because of higher safety of the former than the latter. It is well known that polyphenols such as chlorogenic acids richly contained in coffee (Iwai et al., 2004), and catechins contained in tea (Gardner, McPhail, \& Duthie, 1998), and ascorbic acid (Gil,

71 Tomas-Barberan, Hess-Pierce, \& Kader, 2000) have strong antioxidant activity.

Recently, it has been reported that antioxidants are contained in the by-product of some food such as defatted rice bran (Wiboonsirikul et al., 2007a) and black rice bran (Wiboonsirikul, Hata, Tsuno, Kimura, \& Adachi, 2007b). The higher the radical scavenging activity of defatted rice bran extracts, the higher the temperature for extraction ranging from 50 to $250{ }^{\circ} \mathrm{C}$ (Wiboonsirikul

et al., 2007a). CS extracts that is obtained by the treatments with methanol and water have antioxidant activity (Borrelli et al., 2004). However, the research on the effect of the extraction temperature on the antioxidant activity of CS extracts has not yet been reported. It is expected that the antioxidant activity of CS extracts would be improved by subcritical water treatments.

The purpose of the present study is to evaluate the antioxidant activity of CS extracts obtained

82 antioxidant capacities and the amount of antioxidant components such as protein and total 83 phenolic compounds in the extracts. 
85 2. Materials and methods

2.1. Materials and reagents

88

Coffee silverskin (CS) produced by roasting coffee beans (Coffeea arabica cv. Brazil, $C$. arabica $\mathrm{cv}$. Colombia, C. canephora var. robusta cv. Vietnum, and C. canephora var. robusta cv.

91 Indonesia) was obtained from UCC Ueshima Coffee Co., Kobe, Japan. CS easily peels off 92 roasted coffee beans in the roasting process of green coffee beans. The function to separate CS 93 and roasted coffee beans is attached to most industrial coffee roasting machines. CS separated 94 from roasted coffee beans in the iron pot of roasting machine is collected by aspiration of air to 95 another container. Trolox (lot 648471) was purchased from Calbiochem (San Diego, CA, USA). 96 Fluorescein sodium salt (lot 079K0141V) was from Sigma (St. Louis, MO, USA). 2,2'-Azobis(2amidinopropane) dihydrochloride (AAPH, lot STN0525) was from Wako Pure Chemical (Osaka, Japan). 1,1-Diphenyl-2-picrylhydrazyl (DPPH, lot M9R6579), gallic acid (lot M9R9781), phenol reagent solution (Folin-Ciocalteu's reagent solution, lot L2286), chlorogenic acid hemihydrate (5CQA, lot M8N8455), caffeine, anhydrous (lot M7T9075), 5-(hydroxymethyl)-2-furfural (5-HMF, 101 lot M9M3597). Bovine serum albumin (BSA, lot M6P3104) and all other chemicals were of reagent grade and were from Nacalai Tesque (Kyoto, Japan).

2.2. Preparation of CS extracts by the treatments with water, $0.1 \mathrm{M} \mathrm{HCl}$, and $0.1 \mathrm{M} \mathrm{NaCl}$ at 25 ${ }^{\circ} \mathrm{C}$ and $80{ }^{\circ} \mathrm{C}$. 
110 Kiriyama No. 5C filter paper. The filtrate was concentrated with a rotary evaporator. The 111 concentrated sample was freeze-dried and stored at $-20{ }^{\circ} \mathrm{C}$.

2.3. Subcritical water treatment of CS.

One gram of CS and $50 \mathrm{ml}$ of distilled water were put in a reaction vessel of SUS-316 stainless

steel (Taiatsu Techno Co., Osaka, Japan). The vessel was set in a portable reactor model TPR-1

(TVS-N2 specification) (Taiatsu Techno Co.) and heated to a prescribed temperature (180, 210,

to reach the temperatures of $180,210,240$, and $270{ }^{\circ} \mathrm{C}$, respectively, from $25{ }^{\circ} \mathrm{C}$. Then the

121 mixture in the vessel was filtered firstly through Kiriyama No. 3 filter paper, and the filtrate was

filtered secondly through Kiriyama No. 5C filter paper. The filtrate was concentrated with a rotary evaporator. The concentrated sample was freeze-dried and stored at $-20{ }^{\circ} \mathrm{C}$.

\subsection{HPLC analysis of caffeine, 5-CQA, and 5-HMF.}

HPLC analysis of caffeine, 5-CQA, and 5-HMF in CS extracts was performed according to the

procedures previously reported (Narita \& Inouye, 2011) with some modifications. The CS extract

solution $(10 \mathrm{mg} / \mathrm{ml})$ was applied to reversed-phase column chromatography in a preparative

HPLC 7400 system (GL Science, Tokyo, Japan) on an Inertsil ODS-3 [4.6 mm (inner diameter or

ID) $\times 15.0 \mathrm{~cm}$ ] column $\left(\mathrm{GL}\right.$ Science) at the column temperature of $35^{\circ} \mathrm{C}$. The mobile phase was

composed of solvents $\mathrm{A}\left(50 \mathrm{mM}\right.$ acetic acid in $\left.\mathrm{H}_{2} \mathrm{O}\right)$ and $\mathrm{B}(50 \mathrm{mM}$ acetic acid in acetonitrile),

133 and the gradient program was as follows: 0-30.0 min, 0-20\% (v/v) of B; 30.0-45.0 min, 20-35\%

$134(\mathrm{v} / \mathrm{v})$ of $\mathrm{B} ; 45.0-50.0 \mathrm{~min}, 35-80 \%(\mathrm{v} / \mathrm{v})$ of $\mathrm{B} ; 50.0-50.1 \mathrm{~min}, 80-5 \%(\mathrm{v} / \mathrm{v})$ of $\mathrm{B}$; and $50.1-60$

$135 \min , 0 \%(\mathrm{v} / \mathrm{v})$ of $\mathrm{B}$. The injection volume of the CS extract solution was $10 \mu \mathrm{l}$ and a flow-rate 
136 was $1.0 \mathrm{ml} / \mathrm{min}$. Caffeine, 5-CQA, and 5-HMF were detected by respective absorption at 270, 325,

137 and $284 \mathrm{~nm}$ with a photodiode array. Caffeine, 5-CQA, and 5-HMF in the CS extract were 138 identified by comparing the retention times and the UV spectra of the standard materials. The 139 detection limits of all quantitative analyses were $10 \mu \mathrm{g} / \mathrm{ml}$.

2.5. Determination of total sugar contents.

Total sugar contents of CS extracts were determined by the phenol-sulfuric method (Dubois,

Gilles, Hamilton, Rebers, \& Smith, 1956). The CS extract solution was prepared to the

concentration of $1.0 \mathrm{mg} / \mathrm{ml}$ using distilled water. Zero-point-five $\mathrm{ml}$ of $5 \%(\mathrm{w} / \mathrm{w})$ phenol was

added to $0.5 \mathrm{ml}$ of the CS extract solution of $1.0 \mathrm{mg} / \mathrm{ml}$, followed by adding quickly $2.0 \mathrm{ml}$ of

$\mathrm{H}_{2} \mathrm{SO}_{4}$, and the mixture was mixed well. The mixture was left for $40 \mathrm{~min}$ at $25{ }^{\circ} \mathrm{C}$ in a water bath.

The absorbance at $490 \mathrm{~nm}$ was measured using a spectrophotometer. The total sugar contents of the CS extracts were determined using standard curves obtained with D-glucose.

\subsection{Determination of reducing sugar contents.}

Reducing sugar contents of CS extracts were determined by the 3,5-dinitrosalicylic acid (DNS)

method (Borel, Hostettler, \& Deuel, 1952). The DNS reagent solution consisting of $10 \mathrm{~g}$ DNS,

$0.5 \mathrm{~g}$ sodium sulfate, $2 \mathrm{~g}$ phenol, and $10 \mathrm{~g}$ sodium hydroxide in 1,000 $\mathrm{ml}$ distilled water was

prepared. The CS extract solutions of $1.0 \mathrm{mg} / \mathrm{ml}$ were prepared using distilled water. One $\mathrm{ml}$ of the extract solution and $3 \mathrm{ml}$ of the DNS reagent solution were mixed and heated in boiling water for $5 \mathrm{~min}$. The mixture was cooled to room temperature, followed by the addition of $21 \mathrm{ml}$ of 


\subsection{Determination of protein.}

163

Protein content of CS extracts was determined by the Lowry-Folin method (Lowly, Rosebrough, Farr, \& Randall, 1951). The Lowry's solution was prepared by mixing $50 \mathrm{ml}$ of 5\% (w/v) $\mathrm{Na}_{2} \mathrm{CO}_{3}$ aqueous solution, $0.5 \mathrm{ml}$ of $2 \%(\mathrm{w} / \mathrm{v})$ sodium potassium tartrate aqueous solution, and $0.5 \mathrm{ml}$ of $1 \%(\mathrm{w} / \mathrm{v}) \mathrm{CuSO}_{4}$ aqueous solution. Zero-point-two $\mathrm{ml}$ of the CS extract solution and $0.2 \mathrm{ml}$ of $2 \mathrm{M} \mathrm{NaOH}$ were mixed and stood for $20 \mathrm{~min}$ at $25^{\circ} \mathrm{C}$. Then the mixture was added to $2.0 \mathrm{ml}$ of the Lowry's solution and stood for $20 \mathrm{~min}$ at $25{ }^{\circ} \mathrm{C}$. Next, the Folin-reagent was added to the mixture and left for $20 \mathrm{~min}$ at $25{ }^{\circ} \mathrm{C}$. The absorbance at $750 \mathrm{~nm}$ was measured using a spectrophotometer. The protein contents of the CS extracts were determined using standard curves obtained with BSA.

\subsection{Determination of total phenolic contents.}

Total phenolic contents of CS extracts were determined using a previously reported procedure with the Folin-Ciocalteu's reagent (Singleton \& Rossi, 1965). Zero-point-two ml of $1.0 \mathrm{mg} / \mathrm{ml} \mathrm{CS}$ extract was added to $1.8 \mathrm{ml}$ of distilled water followed by $1.0 \mathrm{ml}$ of the Folin-Ciocalteu's reagent. The mixture was left for $3 \mathrm{~min}$ at $25^{\circ} \mathrm{C}$. Then $5.0 \mathrm{ml}$ of $0.4 \mathrm{M}$ sodium carbonate was added to the mixture. The mixture was incubated at $25{ }^{\circ} \mathrm{C}$ for $1 \mathrm{~h}$. The absorbance at $765 \mathrm{~nm}\left(A_{765}\right)$ was measured using a spectrophotometer and the phenolic contents in CS extracts were evaluated by a standard curve obtained with gallic acid.

\subsection{Measurement of DPPH radical scavenging activity}

The DPPH radical scavenging activity of CS extracts was assayed by the previously reported method (Aoshima \& Ayabe, 2007) with some modifications. Zero-point-two ml of various 
188 concentrations of CS extract solution prepared using $50 \%(\mathrm{v} / \mathrm{v})$ ethanol aqueous solution were 189 mixed with $0.3 \mathrm{ml}$ of $0.2 \mathrm{mM} \mathrm{DPPH}$ in ethanol and $0.5 \mathrm{ml}$ of $0.5 \mathrm{M}$ acetic acid buffer at $\mathrm{pH} 5.5$.

190 The mixture was shaken vigorously and placed in the dark for $30 \mathrm{~min}$ at $25^{\circ} \mathrm{C}$. The decrease in 191 the absorbance at $517 \mathrm{~nm}\left(A_{517}\right)$ of DPPH was measured using a spectrophotometer. The DPPH 192 radical scavenging activity was calculated by equation 1.

where $A_{\mathrm{s}}$ is $A_{517}$ of the mixture in the presence of the sample and DPPH, $A_{\mathrm{b}}$ is $A_{517}$ of the mixture in the absence of the sample and DPPH (blank), and $A_{0}$ is $A_{517}$ of the mixture in the absence of the sample and in the presence of DPPH. The DPPH values of the each sample are expressed as the amount ( $\mu \mathrm{mol})$ of trolox equivalents (TE) per gram of the CS extract.

2.10. Measurement of hydrophilic oxygen radical absorbance capacity (H-ORAC)

The H-ORAC assay was carried out according to the previously reported method (Prior et al., 2003) with some modifications. Fluorescein and AAPH solutions were prepared to the concentrations of $94.4 \mathrm{nM}$ and $31.7 \mathrm{mM}$, respectively, using $75 \mathrm{mM}$ potassium phosphate buffer initial fluorescence $\left(f_{0 \mathrm{~min}}\right)$ of each well was measured at the excitation and emission wavelengths of 492 and 530 nm, respectively. An MTP-800Lab micro-titer-plate reader (Corona Electric Co., 210 Ibaraki, Japan) with 492 excitation and 530 emission cut-off filters was used for fluorescence 211 measuring. The mixture was pre-incubated at $37{ }^{\circ} \mathrm{C}$ for $10 \mathrm{~min}$, and the reaction was initiated by 212 adding $75 \mu \mathrm{l}$ of $31.7 \mathrm{mM}$ AAPH solution. The fluorescence depletion was monitored every $2 \mathrm{~min}$ 213 for $90 \min$ (from $f_{2 \min }$ to $f_{90 \mathrm{~min}}$ ) at the excitation and emission wavelengths of 492 and $530 \mathrm{~nm}$, 
214 respectively. The area under the fluorescence decay curve (AUC) was calculated according to the 215 following equation 2.

216

$217 \quad \mathrm{AUC}=\left(0.5 \times f_{8 \min }+f_{10 \min }+f_{14 \min }+\ldots+f_{88 \min }+0.5 \times f_{90 \min }\right) / f_{0 \min } \times 2$

The net AUC was calculated as follows:

221 net $\mathrm{AUC}=\mathrm{AUC}-\mathrm{AUC}_{\mathrm{blank}}$

where $\mathrm{AUC}_{\text {blank }}$ is the $\mathrm{AUC}$ value obtained with buffer $\mathrm{A}$ instead of the CS extract solution. The secondary regression equation between the concentration of trolox standard solutions and the AUC was calculated. The H-ORAC values of the CS extract solutions were calculated according

to equation 4 , and were expressed as $\mu$ mol of TE per gram of the CS extract.

H-ORAC $(\mu \mathrm{mol} \mathrm{TE} / \mathrm{g}$ of CS extract $)=\mathrm{a} \times(\text { net AUC })^{2}+\mathrm{b} \times$ net $\mathrm{AUC}+\mathrm{c}$

where $\mathrm{a}, \mathrm{b}$, and c were constants of secondary regression of equation 4 .

3. Results and discussion

3.1. Yields of CS extracts obtained by the treatments of CS with water, $0.1 \mathrm{M} \mathrm{HCl}$, and $0.1 \mathrm{M}$

CS extracts were obtained by the treatments with water, $0.1 \mathrm{M} \mathrm{HCl}$, and $0.1 \mathrm{M} \mathrm{NaOH}$ at 
240 extraction temperatures from 25 to $210{ }^{\circ} \mathrm{C}$, although it decreased with increasing the temperature 241 exceeding $210{ }^{\circ} \mathrm{C}$. The highest yield of the CS extracts by the treatment with water was given at 242 the extraction temperature of $210{ }^{\circ} \mathrm{C}$, and the yield was $29 \%$ (w/w), being one point eight times as 243 high as that $(16 \%, \mathrm{w} / \mathrm{w})$ obtained at $25{ }^{\circ} \mathrm{C}$ (Table 1$)$. It was reported previously that the yields of 244 the CS extracts by the treatment with water at $25{ }^{\circ} \mathrm{C}$ and $121{ }^{\circ} \mathrm{C}$ were $14 \%$ and $20 \%$, respectively 245 (Furusawa et al., 2011). The yield at $121{ }^{\circ} \mathrm{C}$ was estimated to be $21 \%$ by extrapolating the data in 246 Table 1, and this value is in reasonable agreement with that of Furusawa et al. The yield was 247 considerably different by changing the extracting solvent from water to $0.1 \mathrm{M} \mathrm{HCl}$ and $0.1 \mathrm{M}$ $248 \mathrm{NaOH}$, although the extraction temperatures with those solvents were allowed only at $25{ }^{\circ} \mathrm{C}$ and $24980{ }^{\circ} \mathrm{C}$ (Table 1). The apparent highest yield (44\%) was given by the treatment with $0.1 \mathrm{M} \mathrm{NaOH}$ 250 at $80{ }^{\circ} \mathrm{C}$ among the conditions examined. This apparent highest yield shows the dry weight of CS 251 extracts obtained by freeze-drying filtration of mixture incubated $1 \mathrm{~g}$ CS and $50 \mathrm{ml}$ of $0.1 \mathrm{M}$ $252 \mathrm{NaOH}$ at $80{ }^{\circ} \mathrm{C}$ for $1 \mathrm{~h}$. Therefore, it is thought that about $20 \%$ of the apparent yield was re253 solidified $\mathrm{NaOH}$ or sodium salt given by the treatment of $1 \mathrm{~g} \mathrm{CS}$ with $50 \mathrm{ml}$ of $0.1 \mathrm{M} \mathrm{NaOH}$ at 80 $254{ }^{\circ} \mathrm{C}$ for $1 \mathrm{~h}$.

(Table 1)

\subsection{HPLC of caffeine, 5-CQA, and 5-HMF of CS extracts.}

260 It is reported that hexose and pentose are decomposed to mainly 5-HMF and furfural in the 261 process by subcritical water treatment (Khajavi, Kimura, Oomori, Matsuno, \& Adachi, 2005; 262 Usuki, Kimura, \& Adachi, 2008). We analyzed caffeine and 5-CQA which are the main 263 polyphenols in coffee beans and 5-HMF in the CS extracts by reversed-phase HPLC (Fig. 1).

264 The peak of caffeine was observed at the elution time of $13.8 \mathrm{~min}$. The amounts of caffeine 265 extracted from $1 \mathrm{~g} \mathrm{CS}$ by the treatment with water were in the range of $4.1-4.4 \mathrm{mg}$, being 
266 substantially the same without depending on the extraction temperature from 180 to $270{ }^{\circ} \mathrm{C}$

267 (Table 2). It was reported that the percentage yield of caffeine extracted by subcritical water 268 extraction from tea waste increased depending on the increase in the extraction temperature from $269100{ }^{\circ} \mathrm{C}$ to $175{ }^{\circ} \mathrm{C}$, and the highest value obtained at $175{ }^{\circ} \mathrm{C}$ was $0.77 \%$ (w/w) namely $7.7 \mathrm{mg} / \mathrm{g}$ 270 (Shalmashi, Abedi, Golmohammad, \& Eikani, 2010). This difference might be due to that most of 271 all caffeine is contained in CS could be extracted even at $25{ }^{\circ} \mathrm{C}$, although caffeine in tea waste is 272 located in the state so as to be extracted by the degradation of cell walls and other cell 273 components (Table 2). Another point is the extraction time with subcritical water. In the present 274 study, we applied $10 \mathrm{~min}$ for extraction to CS, whereas $120 \mathrm{~min}$ was applied to tea waste. At least, 275 it was suggested that caffeine in CS extracts is not decomposed by subcritical water at 180-270 $276{ }^{\circ} \mathrm{C}$ from this experimental result. The amounts $(4.1-4.2 \mathrm{mg})$ of caffeine extracted from $1 \mathrm{~g}$ CS by 277 the treatment with $0.1 \mathrm{M} \mathrm{HCl}$ at 25 and $80{ }^{\circ} \mathrm{C}$ were the same. The amounts $(1.7-1.8 \mathrm{mg})$ of 278 caffeine extracted from $1 \mathrm{~g} \mathrm{CS}$ by the treatment with $0.1 \mathrm{M} \mathrm{NaOH}$ at 25 and $80{ }^{\circ} \mathrm{C}$ were almost 279 the same, and were lower than those of the CS extracts obtained by treatment with water and $280 \quad 0.1 \mathrm{M} \mathrm{HCl}$. This cause seems that the solubility of caffeine is lowered in $0.1 \mathrm{M} \mathrm{NaOH}$ at high $\mathrm{pH}$ 281 ( $\mathrm{pH}$ is around 13) because it is a basic material (Table 2).

282 5-CQA was detected in the CS extracts obtained by the treatments with water at 25,80 , and $283180{ }^{\circ} \mathrm{C}$ (Table 2), although it was not detected in the CS extracts obtained by the treatments with 284 water at 210,240 , and $270{ }^{\circ} \mathrm{C}$ (Table 2). These results suggest that 5-CQA in CS treated by 285 subcritical water above $210{ }^{\circ} \mathrm{C}$ was decomposed. It is known that a progressive destruction and 286 transformation of chlorogenic acid with $8-10 \%$ being lost for every $1 \%$ loss of dry matter during 287 roasting of coffee beans (Clifford, 1999).

288 No difference was observed in the amounts $(1.1 \mathrm{mg})$ of 5-CQA extracted from $1 \mathrm{~g}$ CS with 0.1 $289 \mathrm{M} \mathrm{HCl}$ at $25{ }^{\circ} \mathrm{C}$ and $80{ }^{\circ} \mathrm{C}$ were the same. However, 5-CQA was not detected in the CS extracts 290 obtained with $0.1 \mathrm{M} \mathrm{NaOH}$ at $25{ }^{\circ} \mathrm{C}$ and $80{ }^{\circ} \mathrm{C}$. It was reported that caffeic acid and chlorogenic 291 acid are stable in phosphate or acetate buffer in acid pH (3-6) (Friedman \& Jurgens, 2000). 
292 However, they are unstable in borate buffer $(\mathrm{pH} \mathrm{7-11)} \mathrm{with} \mathrm{an} \mathrm{increase} \mathrm{in} \mathrm{pH}$, and their structural 293 changes are time-dependent and nonreversible (Friedman \& Jurgens, 2000). The cause that 5294 CQA was not detected in CS extracts obtained with $0.1 \mathrm{M} \mathrm{NaOH}(\mathrm{pH}$ is around 13$)$ at $25^{\circ} \mathrm{C}$ and $29580{ }^{\circ} \mathrm{C}$ might be based on the stability of 5-CQA at alkaline $\mathrm{pH}$.

296 The amount of 5-HMF extracted from $1 \mathrm{~g}$ CS increased with increasing the extraction 297 temperature from 25 to $210{ }^{\circ} \mathrm{C}$ and reached the maximum $(2.0 \mathrm{mg})$, while steeply decreased at the 298 temperature over $210{ }^{\circ} \mathrm{C}$ (Table 2). 5-HMF is considered to be a main degradation product formed 299 by dehydration of hexoses through hydrothermolysis (Khajavi et al., 2005; Usuki et al., 2008) and 300 its content in general is almost none. In the present study, CS produced as a by-product of the 301 roasting process of coffee beans over $200{ }^{\circ} \mathrm{C}$. 5-HMF detected in the CS extract obtained by the 302 treatment of $\mathrm{CS}$ with water at $25{ }^{\circ} \mathrm{C}$ could be derived from roasting of coffee beans. The amounts 303 of 5-HMF extracted from $1 \mathrm{~g} \mathrm{CS}$ obtained with $0.1 \mathrm{M} \mathrm{HCl}$ at 25 and $80{ }^{\circ} \mathrm{C}$ were almost the same $304(0.4-0.5 \mathrm{mg})$, but 5-HMF was not detected in the extract obtained by the treatment with $0.1 \mathrm{M}$ $305 \mathrm{NaOH}$ at 25 and $80{ }^{\circ} \mathrm{C}$ (Table 2).

(Table 2)

\subsection{Total sugar and reducing sugar contents of CS extracts.}

312 Table 3 shows the total sugar and reducing sugar contents in $1 \mathrm{~g}$ CS extracts obtained by the 313 treatments under various conditions. The values of the total sugar and reducing sugar contents 314 (mg/g CS extract) were converted to their amounts (mg/g CS) contained in $1 \mathrm{~g}$ CS (Table 3). 315 When $1 \mathrm{~g} \mathrm{CS}$ is treated by water at $25-270{ }^{\circ} \mathrm{C}$, the amounts of total sugar and reducing sugar in 1 316 g CS increased with increasing the extraction temperature from $25{ }^{\circ} \mathrm{C}$ to reach the maximum for 317 both at $180{ }^{\circ} \mathrm{C}$ to the amounts of $121 \pm 9 \mathrm{mg}$ and $52 \pm 2 \mathrm{mg}$, respectively (Table 3 ). However, the 
318 amounts for both decreased at the temperature over $180{ }^{\circ} \mathrm{C}$ and turned to around $15 \mathrm{mg}$ at $270{ }^{\circ} \mathrm{C}$.

319 The total sugar contents of the CS extracts obtained by the treatment with water increased with 320 increasing temperature up to $180{ }^{\circ} \mathrm{C}$ and drastically decreased at the extraction temperature over $321 \quad 180{ }^{\circ} \mathrm{C}$. It was reported that the carbohydrate contents from the defatted rice bran extract obtained 322 by the treatment with water increased with increasing the extraction temperature up to $200{ }^{\circ} \mathrm{C}$, 323 and decreased at the temperature over $200{ }^{\circ} \mathrm{C}$ (Wiboonsirikul et al., 2007a). This profile of the 324 dependence of the carbohydrate contents on the extraction temperature is similar to that shown in 325 Table 3. The decrease in the carbohydrate contents at the temperatures over $200{ }^{\circ} \mathrm{C}$ was 326 considered due to the hydrolysis of poly- or oligosaccharides and the degradation of 327 monosaccharides generated by the high ionic product of water at high temperature under 328 subcritical conditions (Wiboonsirikul et al., 2007a). The decrease in the total sugar contents of 329 the CS extracts at the temperature over $180{ }^{\circ} \mathrm{C}$ would also be ascribed to the same cause. The total 330 sugar and reducing sugar contents of the CS extracts obtained at $240{ }^{\circ} \mathrm{C}$ and $270{ }^{\circ} \mathrm{C}$ were almost 331 the same, suggesting that most of the saccharides produced from the CS extracts obtained at 240 $332{ }^{\circ} \mathrm{C}$ and $270{ }^{\circ} \mathrm{C}$ could be the mixture of monosaccharides. At the extraction temperature of $25{ }^{\circ} \mathrm{C}$ 333 and $80{ }^{\circ} \mathrm{C}$, the efficiency of the extraction solvent for the amounts of the total sugar extracted was 334 in the order of $0.1 \mathrm{M} \mathrm{HCl}>0.1 \mathrm{M} \mathrm{NaOH}>$ water, while that of the reducing sugar was in the 335 order of $0.1 \mathrm{M} \mathrm{HCl}>$ water $>0.1 \mathrm{M} \mathrm{NaOH}$.

(Table 3)

\subsection{Protein and total phenolic contents of CS extracts.}

Table 3 shows the protein and total phenolic contents of $1 \mathrm{~g}$ CS extracts obtained by the 342 treatments under various conditions. The values of the protein and total phenolic contents were 343 converted to their amounts (mg/g CS) contained in $1 \mathrm{~g} \mathrm{CS}$ (Table 3). The protein content in the 
344 CS extract obtained by the treatment with water increased with increasing the extraction 345 temperature from $25{ }^{\circ} \mathrm{C}$ to $240{ }^{\circ} \mathrm{C}$ and the maximum values were observed at $240{ }^{\circ} \mathrm{C}$ being $582 \pm$ $34610 \mathrm{mg}$ per $\mathrm{g}$ of CS extract (Table 3) and their contents extracted from $1 \mathrm{~g}$ CS increased with 347 increasing the temperature, although the maximum was observed at $210{ }^{\circ} \mathrm{C}$ being $157 \pm 4 \mathrm{mg}$ per $348 \mathrm{~g} \mathrm{CS}$ (Table 3). The largest amount of protein was extracted from $1 \mathrm{~g} \mathrm{CS}$ at $210{ }^{\circ} \mathrm{C}$ was about five 349 times as high as that extracted with water at $25{ }^{\circ} \mathrm{C}(33 \pm 2 \mathrm{mg})$. This high extraction degree 350 obtained under the subcritical water condition might due to the enhanced hydrolysis of proteins, 351 solubilization of insoluble proteins, and degradation of cell walls. It is reported that the solubility 352 of the rice bran protein increased by the hydrolysis of proteins and cell wall by subcritical water 353 treatment (Wiboonsirikul et al., 2007a). At the extraction temperature of $25{ }^{\circ} \mathrm{C}$ and $80{ }^{\circ} \mathrm{C}$, the 354 efficacy of the solvent for the protein extraction from $1 \mathrm{~g} \mathrm{CS}$ was in the order of $0.1 \mathrm{M} \mathrm{NaOH}>$ $0.1 \mathrm{M} \mathrm{HCl}>$ water (Table 3). The largest amount of protein was extracted from $1 \mathrm{~g} \mathrm{CS}$ in these 356 conditions was $97 \pm 8 \mathrm{mg}$, and was obtained by extraction with $0.1 \mathrm{M} \mathrm{NaOH}$ at $80{ }^{\circ} \mathrm{C}$. However, 357 the amount of protein was extracted from $1 \mathrm{~g} \mathrm{CS}$ with subcritical water at $210{ }^{\circ} \mathrm{C}$ was about one 358 point five times as high as that extracted with $\mathrm{NaOH}$ at $80{ }^{\circ} \mathrm{C}$ (Table 3 ).

359 The total phenolic content in the CS extract obtained by the treatment with water increased 360 with increasing the extraction temperature from $25{ }^{\circ} \mathrm{C}$ to $240{ }^{\circ} \mathrm{C}$ and the maximum values were 361 observed at $240{ }^{\circ} \mathrm{C}$ being $130 \pm 6 \mathrm{mg}$ per $\mathrm{g}$ of the CS extract (Table 3). The largest amount of total 362 phenolic components $\left(36 \pm 3 \mathrm{mg}\right.$ ) extracted from $1 \mathrm{~g} \mathrm{CS}$ was also observed with water at $210{ }^{\circ} \mathrm{C}$ 363 (Table 3). It was six times as high as it extracted from $1 \mathrm{~g} \mathrm{CS}$ with water at $25{ }^{\circ} \mathrm{C}(6 \pm 0 \mathrm{mg})$. This 364 might also due to the hydrolysis or degradation of polyphenolic compounds such as lignin and 365 lignan into smaller and soluble compounds. At the extraction temperature of $25{ }^{\circ} \mathrm{C}$ and $80{ }^{\circ} \mathrm{C}$, the 366 efficacy of the solvent in the extraction of total phenolic compounds was not much different in 367 these treatments (Table 3 ). The amount of total phenolic components was $5-8 \mathrm{mg} / \mathrm{per} \mathrm{g}$ of CS 368 (Table 3). The amount of total phenolic components was extracted from $1 \mathrm{~g}$ CS with subcritical 
369 water at $210{ }^{\circ} \mathrm{C}$ was about five times as high as that extracted with these solvents at 25 and $80{ }^{\circ} \mathrm{C}$ 370 (Table 3).

3.5. DPPH radical scavenging activity and H-ORAC of CS extracts.

Figure 2A and Table 4 show the results of DPPH radical scavenging activity assay on the CS

extracts obtained by the treatments with water, $0.1 \mathrm{M} \mathrm{HCl}$, and $0.1 \mathrm{M} \mathrm{NaOH}$ at various temperatures. The values of the CS extracts obtained with water increased remarkably in a sigmoid fashion with increasing the extraction temperature from 25 to $270{ }^{\circ} \mathrm{C}$ (Fig. 2A). The maximum value was given with the $\mathrm{CS}$ extract obtained by the treatment with water at $270{ }^{\circ} \mathrm{C}$ was $379 \pm 36 \mu \mathrm{mol}$ TE per g of CS extract (Table 4). The DPPH values of the extracts obtained with water, $0.1 \mathrm{M} \mathrm{HCl}$ or $0.1 \mathrm{M} \mathrm{NaOH}$ at 25 and $80{ }^{\circ} \mathrm{C}$ were substantially the same, and were range of $61-75 \mu \mathrm{mol}$ TE per g of CS extract (Table 4). The DPPH values of CS extraction by treatment with subcritical water at $270{ }^{\circ} \mathrm{C}$ were about five times as high as the values of the extraction by treatment with water, $0.1 \mathrm{M} \mathrm{HCl}$ or $0.1 \mathrm{M} \mathrm{NaOH}$ at 25 and $80{ }^{\circ} \mathrm{C}$ (Table 4).

The H-ORAC values of the CS extracts obtained by the treatments by with water, $0.1 \mathrm{M} \mathrm{HCl}$, and $0.1 \mathrm{M} \mathrm{NaOH}$ at the various temperatures were also examined (Fig. 2A \& Table 4). The values

of the CS extracts obtained with water increased with increasing the temperature also in a sigmoid fashion with increasing the extraction temperature from $25{ }^{\circ} \mathrm{C}$ to $270{ }^{\circ} \mathrm{C}$ (Fig. 2A). The maximum 388 value was given at $270{ }^{\circ} \mathrm{C}$ was $2629 \pm 193 \mu$ mol TE per g of CS extract (Table 4). The values of 389 the extracts obtained with water, $0.1 \mathrm{M} \mathrm{HCl}$, and $0.1 \mathrm{M} \mathrm{NaOH}$ at $25^{\circ} \mathrm{C}$ and $80{ }^{\circ} \mathrm{C}$ were almost the 390 same, and were range of 273-384 $\mu$ mol TE per g of CS extract (Table 4). The H-ORAC values of 391 CS extraction by treatment with subcritical water at $270{ }^{\circ} \mathrm{C}$ were about seven times as high as the 392 values of the extraction by treatment with water, $0.1 \mathrm{M} \mathrm{HCl}$ or $0.1 \mathrm{M} \mathrm{NaOH}$ at 25 and $80{ }^{\circ} \mathrm{C}$ 393 (Table 4). 
394 It is reported that the CS extracts obtained by the treatments with distilled water and methanol 395 have antioxidant activities by two methods, $N, N$-dimethyl- $p$-phenylenediamine (DMPD) for the 396 water extracts and 2,2'-azinobis(3-ethylbenzothiazoline-6-sulfonic acid (ABTS) radical 397 scavenging activity for the methanol extracts (Borrelli et al., 2004). It has not been studied 398 whether the antioxidant activity of the CS extracted with water changes depending on the 399 extraction temperature (Borrelli et al., 2004). There are many methods reported for measuring 400 antioxidative activity. These methods are mainly classified into two types. One is the assay based 401 on hydrogen atom transfer (HAT) which includes the H-ORAC assay and the other is that based 402 on electron transfer (ET) which includes DPPH, ABTS, superoxide dismutase, and ferric reducing 403 antioxidant potential assays (Dudonne, Vitrac, Coutiere, Woillez, \& Merillon, 2009). In the 404 present study, we evaluated the antioxidant activities of CS extracts using DPPH assay and H405 ORAC assay. The H-ORAC and DPPH values of CS extracts obtained by the treatment with 406 water at $25-270{ }^{\circ} \mathrm{C}$, and both values increased remarkably with increasing the extraction 407 temperatures (Fig. 2A \& Table 4) and the highest values (2629 \pm 193 and $379 \pm 36 \mu \mathrm{mol} \mathrm{TE} / \mathrm{g}$ of $408 \mathrm{CS}$ extract) of H-ORAC and DPPH are observed at $270{ }^{\circ} \mathrm{C}$, respectively (Fig. 2A). There is very 409 good correlation between the DPPH and H-ORAC values $(R=0.999)$ (Fig. 2B). The good 410 correlation of the antioxidant activities measured by H-ORAC and DPPH methods was reported 411 also with sorghums (Awika, Rooney, Wu, Prior, \& Cisneros-Zevallos, 2003). Generally, phenolic 412 compounds contribute highly to the antioxidant activity of food, actually the total phenolic 413 contents of CS extracts have high correlation with their H-ORAC and DPPH values with the 414 correlation coefficients $(R)$ of 0.987 and 0.982 , respectively (Fig. 3). It is worthy to note that there 415 is also high correlation between protein contents and their H-ORAC and DPPH values, with the $R$ 416 values of 0.994 and 0.990 , respectively (Fig. 3). Peptides produced by the decomposition of 417 soybean protein and wheat gluten were reported to exhibit strong DPPH radical scavenging 418 activity and antioxidant activity against linoleic acid oxidation in emulsion systems (Park, 419 Morimae, Matsumura, Nakamura, \& Sato, 2008). Peptides produced by hydrolyzing the protein in 
420 CS by subcritical water treatment are considered to show such a high antioxidant capacity. The

421 CS extracts obtained by the treatment with water at $210-270{ }^{\circ} \mathrm{C}$ did not contain 5-CQA, which is

422 thought to be the main antioxidant component of coffee beans, although the extracts showed high 423 antioxidant activity (Table 2 \& Fig. 2A). This antioxidant activity must due to proteins and 424 peptides. It is necessary to clarify the component in the CS extract contributed to the antioxidant 425 capacity by further study in the next step. This study shows that CS contains fairly strong 426 antioxidant activity and proposes that the subcritical water treatment is the effective method for 427 extraction of antioxidant components from CS.

(Table 4)

\section{Conclusions}

The antioxidant activity of CS extracts obtained by the treatment of CS with water and subcritical water increased with increasing the temperature also in a sigmoid fashion with increasing the extraction temperature from $25{ }^{\circ} \mathrm{C}$ to $270{ }^{\circ} \mathrm{C}$. The maximum H-ORAC and DPPH values of the extracts were given at $270{ }^{\circ} \mathrm{C}$ were $2629 \pm 193$ and $379 \pm 36 \mu$ mol TE per $\mathrm{g}$ of CS extract, respectively. On the other hand, the antioxidant activity evaluated by H-ORAC and

DPPH radical scavenging activity of CS extracts obtained by the treatment with water, $0.1 \mathrm{M} \mathrm{HCl}$, and $0.1 \mathrm{M} \mathrm{NaOH}$ at $25{ }^{\circ} \mathrm{C}$ and $80{ }^{\circ} \mathrm{C}$ was almost the same. The antioxidant activity of $\mathrm{CS}$ extracts

440 obtained by the treatment of CS with subcritical water was stronger than that extracted by 441 treatment with water, $0.1 \mathrm{M} \mathrm{HCl}$, and $0.1 \mathrm{M} \mathrm{NaOH}$ at $25^{\circ} \mathrm{C}$ and $80{ }^{\circ} \mathrm{C}$.

442 Phenolic contents of CS extracts obtained by the treatment with water and subcritical water at $443 \quad 25-270{ }^{\circ} \mathrm{C}$ have high correlation with their H-ORAC and DPPH values with the correlation 444 coefficients $(R)$ of 0.987 and 0.982 , respectively. It is worthy to note that there is also high 445 correlation between protein contents and their H-ORAC and DPPH values, with the $R$ values of 
4460.994 and 0.990 , respectively. Peptides produced by hydrolyzing the protein in CS by subcritical 447 water treatment are considered to show such a high antioxidant capacity.

448 The CS extracts could be useful as a good source of antioxidative materials. Furthermore, the 449 treatment using subcritical water was more efficient for production of the antioxidative materials 450 from CS. Besides, it was shown that the subcritical water treatment is effective on extraction of 451 total sugar, reducing sugar, protein, phenolic components, and 5-HMF from CS by adjusting 452 treatment temperature.

453

454 455 
456 References

457

458 Aoshima, H. \& Ayabe, S. (2007). Prevention of the deterioration of polyphenol-rich beverages. 459 Food Chemistry, 100, 350-355.

460 Awika, J. M., Rooney, L. W., Wu, X., Prior, R. L., \& Cisneros-Zevallos, L. (2003). Screening 461 methods to measure antioxidant activity of sorghum (sorghum bicolor) and sorghum products. 462 Journal of Agricultural and Food Chemistry, 51, 6657-6662.

463 Borel, E., Hostettler, F., \& Deuel, H. (1952). Quantitative Zuckerbestimmung mit 3,5464 dinitrosalicylsaure und phenol. Helvetica Chimica Acta, 35, 115-120.

465 Borrelli, R. C., Esposito, F., Napolitano, A., Ritieni, A., \& Fogliano, V. (2004). Characterization 466 of a new potential functional ingredient: coffee silverskin. Journal of Agricultural and Food 467 Chemistry, 52, 1338-1343.

468 Clifford, M. N. (1999). Chlorogenic acids and other cinnamates: Nature, occurrence and dietary 469 burden. Journal of the Science of Food and Agriculture, 79, 362-372.

470 Christen, Y. (2000). Oxidative stress and Alzheimer disease. The American Journal of Clinical $471 \quad$ Nutrition, 71, 621S-629S.

472 Diaz, M. N., Frei, B., Vita, J. A., \& Keaney, J. F., Jr. (1997). Antioxidants and atherosclerotic 473 heart disease. The New England Journal of Medicine, 337, 408-416.

474 Dubois, M., Gilles, K. A., Hamilton, J. K., Rebers, P. A., \& Smith, F. (1956). Colorimetric 475 method for determination of sugars and related substances. Analytical Chemistry, 28, 350-356.

476 Dudonne, S., Vitrac, X., Coutiere, P., Woillez, M., \& Merillon, J.-M. (2009). Comparative study 477 of antioxidant properties and total phenolic content of 30 plant extracts of industrial interest using 
478 DPPH, ABTS, FRAP, SOD, and ORAC assays. Journal of Agricultural and Food Chemistry, 57, $479 \quad 1768-1774$.

480 Friedman, M., \& Jurgens, H. S. (2000). Effect of pH on the stability of plant phenolic compounds. 481 Journal of Agricultural and Food Chemistry, 48, 2101-2110.

482 Furusawa, M., Narita, Y., Iwai, K., Fukunaga, T., \& Nakagiri, O. (2011). Inhibitory effect of a hot 483 water extract of coffee "silverskin" on hyaluronidase. Bioscience, Biotechnology, and 484 Biochemistry, 75, 1205-1207.

485 Gardner, P. T., McPhail, D. B., \& Duthie, G. G. (1998). Electron spin resonance spectroscopic 486 assessment of the antioxidant potential of teas in aqueous and organic media. Journal of the 487 Science of Food and Agriculture, 76, 257-262.

488 Gil, M. I., Tomas-Barberan, F. A., Hess-Pierce, B., \& Kader, A. A. (2000). Antioxidant capacities, 489 phenolic compounds, carotenoids, and vitamin C contents of nectarine, peach, and plum cultivars 490 from California. Journal of Agricultural and Food Chemistry, 50, 4976-4982.

491 Khajavi, S. H., Kimura, Y., Oomori, T., Matsuno, R., \& Adachi, S. (2005). Degradation kinetics 492 of monosaccharides in subcritical water. Journal of Food Engineering, 68, 309-313.

493 Iwai, K., Kishimoto, N., Kakino, Y., Mochida, K., \& Fujita, T. (2004). In vitro antioxidative 494 effects and tyrosinase inhibitory activities of seven hydroxycinnamoyl derivatives in green coffee 495 beans. Journal of Agricultural and Food Chemistry, 52, 4893-4898.

496 Kataoka, M., Wiboonsirikul, J., Kimura, Y., \& Adachi, S. (2008) Properties of extracts from 497 wheat bran by subcritical water treatment. Food Science and Technology Research, 14, 553-556.

498 Lambert, J. D., \& Yang, C. S. (2003). Mechanisms of cancer prevention by tea constituents. The 499 Journal of Nutrition, 133, 3262S-3267S. 
500 Lang, A. E., \& Lozano, A. M. (1998). Parkinson's disease. First of two parts. The New England 501 Journal of Medicine, 339, 1044-1053.

502 Lowry, O. H., Rosebrough, N. J., Farr, A. L., \& Randall, R. J. (1951). Protein measurement with 503 the folin phenol reagent. Journal of Biological Chemistry, 193, 265-275.

504 Miller, D. J., \& Hawthorne, S. B. (1998). Method for determining the solubilities of hydrophobic 505 organics in subcritical water. Analitical Chemistry, 70, 1618-1621.

506 Narita, Y., \& Inouye, K. (2009). Kinetic analysis and mechanism on the inhibition of chlorogenic 507 acid and its components against porcine pancreas $\alpha$-amylase isozymes I and II. Journal of 508 Agricultural and Food Chemistry, 57, 9218-9225.

509 Narita, Y., \& Inouye, K. (2011). Inhibitory effects of chlorogenic acids from green coffee beans 510 and cinnamate derivatives on the activity of porcine pancreas $\alpha$-amylase isozyme I. Food 511 Chemistry, 127, 1532-1539.

512 Park, E. Y., Morimae, M., Matsumura, Y., Nakamura, Y., \& Sato, K. (2008). Antioxidant activity 513 of some protein hydrolysates and their fractions with different isoelectric points. Journal of 514 Agricultural and Food Chemistry, 56, 9246-9251.

515 Prior, R. L., Hoang, H., Gu, L., Wu, X., Bacchiocca, M., Howard, L., et al. (2003). Assays for 516 hydrophilic and lipophilic antioxidant capacity (oxygen radical absorbance capacity $\left(\mathrm{ORAC} \mathrm{CL}_{\mathrm{FL}}\right)$ ) 517 of plasma and other biological and food samples. Journal of Agricultural and Food Chemistry, 51, $518 \quad 3273-3279$.

519 Richelle, M., Tavazzi, I., \& Offord, E. (2001). Comparison of the antioxidant activity of 520 commonly consumed polyphenolic beverages (coffee, cocoa, and tea) prepared per cup serving. 521 Journal of Agricultural and Food Chemistry, 49, 3438-3442. 
522 Shalmashi, A., Abedi, M., Golmohammad, F., \& Eikani, M. H. (2010). Isolation of caffeine from 523 tea waste using subcritical water extraction. Journal of Food Process Engineering, 33, 701-711.

524 Singleton, V. L., \& Rossi, J. A., Jr. (1965). Colorimetry of total phenolics with phosphomolybdic525 phosphotungstic acid reagents. American Journal of Enology and Viticulture, 16, 144-158.

526 Takayanagi, R., Inoguchi, T., \& Ohnaka, K. (2011). Clinical and experimental evidence for 527 oxidative stress as an exacerbating factor of diabetes mellitus. Journal of Clinical Biochemistry 528 and Nutrition, 48, 72-77.

529 Usuki, C., Kimura, Y., \& Adachi, S. (2008). Degradation of pentaoses and hexouronic acids in 530 subcritical water. Chemical Engineering and Technology, 31, 133-137.

531 Wakita, Y., Harada, O., Kuwata, M., Fujimura, T., Yamada, T., \& Suzuki, M., et al. (2004). 532 Preparation of subcritical water-treated okara and its effect on blood pressure in spontaneously 533 hypertensive rats. Food Science and Technology Research, 10, 164-167.

534 Wiboonsirikul, J., Kimura, Y., Kadota, M., Morita, H., Tsuno, T., \& Adachi, S. (2007a). 535 Properties of extracts from defatted rice bran by its subcritical water treatment. Journal of 536 Agricultural and Food Chemistry, 55, 8759-8765.

537 Wiboonsirikul, J., Hata, S., Tsuno, T., Kimura, Y., \& Adachi, S. (2007b). Production of 538 functional substances from black rice bran by its treatment in subcritical water. $L W T-$ Food 539 Science and Technology, 40, 1732-1740. 
541 Figure Captions

543 Fig. 1. HPLC chromatograms of the CS extracts obtained by the treatments of CS with water, 0.1 $544 \mathrm{M} \mathrm{HCl}$, and $0.1 \mathrm{M} \mathrm{NaOH}$ at $25{ }^{\circ} \mathrm{C}$ and $210{ }^{\circ} \mathrm{C}$. The extraction solvents/temperatures: $0.1 \mathrm{M}$ $545 \mathrm{HCl} / 25{ }^{\circ} \mathrm{C}(\mathrm{a}), 0.1 \mathrm{M} \mathrm{NaOH} / 25{ }^{\circ} \mathrm{C}(\mathrm{b})$, water $/ 25{ }^{\circ} \mathrm{C}(\mathrm{c})$, and water $/ 210{ }^{\circ} \mathrm{C}(\mathrm{d})$. The wavelength for 546 detection: $270 \mathrm{~nm}$. Peaks (retention times): 1, 5-HMF (5.4 min); 2, caffeine (13.8 min); and 3, 5547 CQA (16.5 min).

549 Fig. 2. H-ORAC and DPPH values of the CS extracts. Panel A: H-ORAC (open symbols) and 550 DPPH (solid symbols) values of the CS extracts obtained by the treatments of CS with water 551 (circles), $0.1 \mathrm{M} \mathrm{HCl}$ (triangles), and $0.1 \mathrm{M} \mathrm{NaOH}$ (squares) at various temperatures. Each point 552 represents the mean and standard deviation of triplicate experiments. Panel B: Relationship 553 between the H-ORAC and DPPH values of the CS extracts obtained by the treatments of CS with 554 water in the temperature range of $25-270{ }^{\circ} \mathrm{C}$.

556 Fig. 3. Relationship between the H-ORAC or DPPH values and protein or total phenolic contents 557 of the CS extracts. The symbols, open circles, solid circles, open triangles, and solid triangles 558 represent the H-ORAC values against total phenolic contents, DPPH values against total phenolic 559 contents, H-ORAC values against total protein contents, and DPPH values against protein 560 contents of the CS extracts, respectively. 
563 Table 1. Yield of the CS extracts ${ }^{a}$

\begin{tabular}{|c|c|c|c|}
\hline \multirow[t]{2}{*}{564} & \multicolumn{2}{|c|}{ Extraction } & \multirow{2}{*}{$\frac{\text { Yield }}{(\%, \mathrm{w} / \mathrm{w})}$} \\
\hline & solvent & temperature $\left({ }^{\circ} \mathrm{C}\right)$ & \\
\hline \multirow[t]{2}{*}{565} & water & 25 & $16 \pm 1$ \\
\hline & water & 80 & $19 \pm 1$ \\
\hline \multirow{2}{*}{566} & water & 180 & $25 \pm 1$ \\
\hline & water & 210 & $29 \pm 1$ \\
\hline \multirow{3}{*}{567} & water & 240 & $27 \pm 1$ \\
\hline & water & 270 & $23 \pm 1$ \\
\hline & $0.1 \mathrm{M} \mathrm{HCl}$ & 25 & $21 \pm 2$ \\
\hline \multirow[t]{3}{*}{568} & $0.1 \mathrm{M} \mathrm{HCl}$ & 80 & $28 \pm 2$ \\
\hline & $0.1 \mathrm{M} \mathrm{NaOH}$ & 25 & $37 \pm 1$ \\
\hline & $0.1 \mathrm{M} \mathrm{NaOH}$ & 80 & $44 \pm 1$ \\
\hline
\end{tabular}

$570{ }^{a}$ Each value is a mean of triplicate analysis \pm standard deviation. 
572 Table 2. Caffeine, 5-CQA, and 5-HMF contents of 1 g CS or CS extracts ${ }^{a}$

573

\begin{tabular}{|c|c|c|c|c|c|c|c|}
\hline \multicolumn{2}{|c|}{ Extraction } & \multicolumn{2}{|c|}{ Caffeine } & \multicolumn{2}{|c|}{ 5-CQA } & \multicolumn{2}{|c|}{ 5-HMF } \\
\hline solvent & temperature $\left({ }^{\circ} \mathrm{C}\right)$ & $(\mathrm{mg} / \mathrm{g}$ of $\mathrm{CS}$ extract) & $(\mathrm{mg} / \mathrm{g}$ of $\mathrm{CS})$ & (mg/g of CS extract) & $(\mathrm{mg} / \mathrm{g}$ of $\mathrm{CS})$ & $(\mathrm{mg} / \mathrm{g}$ of $\mathrm{CS}$ extract $)$ & $(\mathrm{mg} / \mathrm{g}$ of $\mathrm{CS})$ \\
\hline water & 25 & $26.4 \pm 0.1$ & $4.1 \pm 0.1$ & $6.4 \pm 0.3$ & $1.0 \pm 0.0$ & $1.1 \pm 0.1$ & $0.2 \pm 0.0$ \\
\hline water & 80 & $23.1 \pm 0.3$ & $4.4 \pm 0.2$ & $9.0 \pm 0.4$ & $1.7 \pm 0.1$ & $1.1 \pm 0.2$ & $0.2 \pm 0.0$ \\
\hline water & 180 & $16.2 \pm 0.2$ & $4.1 \pm 0.1$ & $6.1 \pm 0.2$ & $1.5 \pm 0.1$ & $4.6 \pm 0.3$ & $1.2 \pm 0.1$ \\
\hline water & 210 & $14.4 \pm 0.1$ & $4.2 \pm 0.1$ & N. D. ${ }^{b}$ & N. D. & $6.9 \pm 0.3$ & $2.0 \pm 0.1$ \\
\hline water & 240 & $15.8 \pm 0.1$ & $4.2 \pm 0.2$ & N. D. & N. D. & $3.8 \pm 0.1$ & $1.0 \pm 0.0$ \\
\hline water & 270 & $17.9 \pm 0.1$ & $4.1 \pm 0.2$ & N. D. & N. D. & $1.8 \pm 0.3$ & $0.4 \pm 0.1$ \\
\hline $0.1 \mathrm{M} \mathrm{HCl}$ & 25 & $19.0 \pm 0.2$ & $4.1 \pm 0.3$ & $5.3 \pm 0.2$ & $1.1 \pm 0.0$ & $1.8 \pm 0.2$ & $0.4 \pm 0.0$ \\
\hline $0.1 \mathrm{M} \mathrm{HCl}$ & 80 & $15.3 \pm 0.2$ & $4.2 \pm 0.3$ & $3.8 \pm 0.1$ & $1.1 \pm 0.1$ & $1.7 \pm 0.2$ & $0.5 \pm 0.1$ \\
\hline $0.1 \mathrm{M} \mathrm{NaOH}$ & 25 & $5.0 \pm 0.2$ & $1.8 \pm 0.1$ & N. D. & N. D. & N. D. & N. D. \\
\hline $0.1 \mathrm{M} \mathrm{NaOH}$ & 80 & $3.9 \pm 0.3$ & $1.7 \pm 0.1$ & N. D. & N. D. & N. D. & N. D. \\
\hline
\end{tabular}

$576{ }^{a}$ Each value is a mean of triplicate analysis \pm standard deviation.

$577 \quad{ }^{b}$ Not detected.

578 
580 Table 3. Total sugar, reducing sugar, protein and total phenolic contents of $1 \mathrm{~g} \mathrm{CS}$ or CS extracts ${ }^{a}$

\begin{tabular}{|c|c|c|c|c|c|c|c|c|c|c|c|c|c|c|c|c|c|c|c|c|}
\hline \multirow{3}{*}{581} & \multicolumn{2}{|c|}{ Extraction } & \multicolumn{5}{|c|}{ Total sugar } & \multicolumn{5}{|c|}{ Reducing sugar } & \multicolumn{5}{|c|}{ Protein } & \multicolumn{3}{|c|}{ Total phenolic } \\
\hline & \multirow{2}{*}{$\begin{array}{r}\text { solvent } \\
\text { water }\end{array}$} & \multirow{2}{*}{$\frac{\text { temperature }\left({ }^{\circ} \mathrm{C}\right)}{25}$} & \multicolumn{2}{|c|}{ ( $\mathrm{mg} / \mathrm{g}$ of $\mathrm{CS}$ extract) } & \multicolumn{3}{|c|}{$(\mathrm{mg} / \mathrm{g}$ of $\mathrm{CS})$} & \multicolumn{2}{|c|}{ ( $\mathrm{mg} / \mathrm{g}$ of $\mathrm{CS}$ extract $)$} & \multicolumn{3}{|c|}{$(\mathrm{mg} / \mathrm{g}$ of $\mathrm{CS})$} & \multicolumn{2}{|c|}{ (mg/g of CS extract) } & \multicolumn{3}{|c|}{$(\mathrm{mg} / \mathrm{g}$ of $\mathrm{CS})$} & \multicolumn{2}{|c|}{ (mg/g of CS extract) } & $(\mathrm{mg} / \mathrm{g}$ of $\mathrm{CS}$ \\
\hline & & & $366 \pm$ & $\pm \quad 21$ & 57 & \pm & 2 & $156 \pm$ & 4 & 25 & \pm & 1 & 212 & $\pm \quad 18$ & & \pm & 2 & 36 & \pm 3 & $6 \pm 0$ \\
\hline \multirow{7}{*}{582} & water & 80 & $405 \pm$ & $\pm \quad 30$ & 77 & \pm & 9 & $155 \pm$ & 9 & 28 & \pm & 2 & 236 & $\pm \quad 12$ & 45 & \pm & 3 & 35 & \pm 1 & $7 \pm 0$ \\
\hline & water & 180 & $477 \pm$ & $\pm \quad 29$ & 121 & \pm & 9 & $206 \pm$ & 6 & 52 & \pm & 2 & 378 & \pm 20 & 95 & \pm & 5 & 85 & \pm 5 & $22 \pm 1$ \\
\hline & water & 210 & $228 \pm$ & 5 & 67 & \pm & 3 & $137 \pm$ & 3 & 40 & \pm & 1 & 535 & $\pm \quad 14$ & 157 & \pm & 4 & 124 & \pm 9 & $36 \pm 3$ \\
\hline & water & 240 & $86 \pm$ & 1 & 23 & \pm & 1 & $82 \pm$ & $\pm \quad 10$ & 21 & \pm & 3 & 582 & \pm 10 & 155 & \pm & 7 & 130 & \pm 6 & $35 \pm 2$ \\
\hline & water & 270 & $71 \pm$ & 6 & 16 & \pm & 1 & $70 \pm$ & 4 & 15 & \pm & 1 & 544 & $\pm \quad 11$ & 125 & \pm & 4 & 123 & \pm 9 & $28 \pm 1$ \\
\hline & $0.1 \mathrm{M} \mathrm{HCl}$ & 25 & $304 \pm$ & $\pm \quad 13$ & 65 & \pm & 7 & $122 \pm$ & 1 & 26 & \pm & 2 & 189 & \pm & 40 & \pm & 4 & 23 & \pm 1 & $5 \pm 1$ \\
\hline & $0.1 \mathrm{M} \mathrm{HCl}$ & 80 & $345 \pm$ & $\pm \quad 10$ & 95 & \pm & 4 & $115 \pm$ & 5 & 32 & \pm & 1 & 183 & \pm 13 & 50 & \pm & 7 & 24 & \pm 1 & $7 \pm 0$ \\
\hline \multirow{2}{*}{583} & $0.1 \mathrm{M} \mathrm{NaOH}$ & 25 & $168 \pm$ & $\pm \quad 14$ & 62 & \pm & 7 & $55 \pm$ & $\pm \quad 18$ & 20 & \pm & 8 & 205 & $\pm \quad 15$ & 76 & \pm & 8 & 15 & \pm 2 & $5 \pm 1$ \\
\hline & $0.1 \mathrm{M} \mathrm{NaOH}$ & 80 & $185 \pm$ & $\pm \quad 28$ & 80 & \pm & 12 & $49 \pm$ & $\pm \quad 12$ & 21 & \pm & 5 & 221 & $\pm \quad 17$ & 97 & \pm & 8 & 19 & \pm 2 & $8 \pm 1$ \\
\hline
\end{tabular}

$584{ }^{a}$ Each value is a mean of triplicate analysis \pm standard deviation. 
586 Table 4. DPPH radical scavenging activity and H-ORAC of CS extracts ${ }^{a}$

\begin{tabular}{|c|c|c|c|c|}
\hline \multirow[t]{2}{*}{587} & \multicolumn{2}{|c|}{ Extraction } & \multirow{2}{*}{$\begin{array}{c}\text { H-ORAC } \\
(\mu \mathrm{mol} \text { TE/g of CS extract })\end{array}$} & \multirow{2}{*}{$\begin{array}{c}\text { DPPH } \\
(\mu \mathrm{mol} \mathrm{TE} / \mathrm{g} \text { of CS extract })\end{array}$} \\
\hline & solvent & temperature $\left({ }^{\circ} \mathrm{C}\right)$ & & \\
\hline \multirow{2}{*}{588} & water & 25 & $354 \pm 44$ & $74 \pm 13$ \\
\hline & water & 80 & $384 \pm 58$ & $75 \pm 18$ \\
\hline \multirow{3}{*}{589} & water & 180 & $1223 \pm 65$ & $184 \pm 28$ \\
\hline & water & 210 & $2321 \pm 169$ & $323 \pm 39$ \\
\hline & water & 240 & $2611 \pm 150$ & $371 \pm 33$ \\
\hline \multirow{2}{*}{590} & water & 270 & $2629 \pm 193$ & $379 \pm 36$ \\
\hline & $0.1 \mathrm{M} \mathrm{HCl}$ & 25 & $289 \pm 34$ & $67 \pm 9$ \\
\hline \multirow{3}{*}{591} & $0.1 \mathrm{M} \mathrm{HCl}$ & 80 & $284 \pm 37$ & $71 \pm 11$ \\
\hline & $0.1 \mathrm{M} \mathrm{NaOH}$ & 25 & $275 \pm 22$ & $61 \pm 5$ \\
\hline & $0.1 \mathrm{M} \mathrm{NaOH}$ & 80 & $273 \pm 20$ & $63 \pm 6$ \\
\hline
\end{tabular}

592

$593{ }^{a}$ Each value is a mean of triplicate analysis \pm standard deviation. 

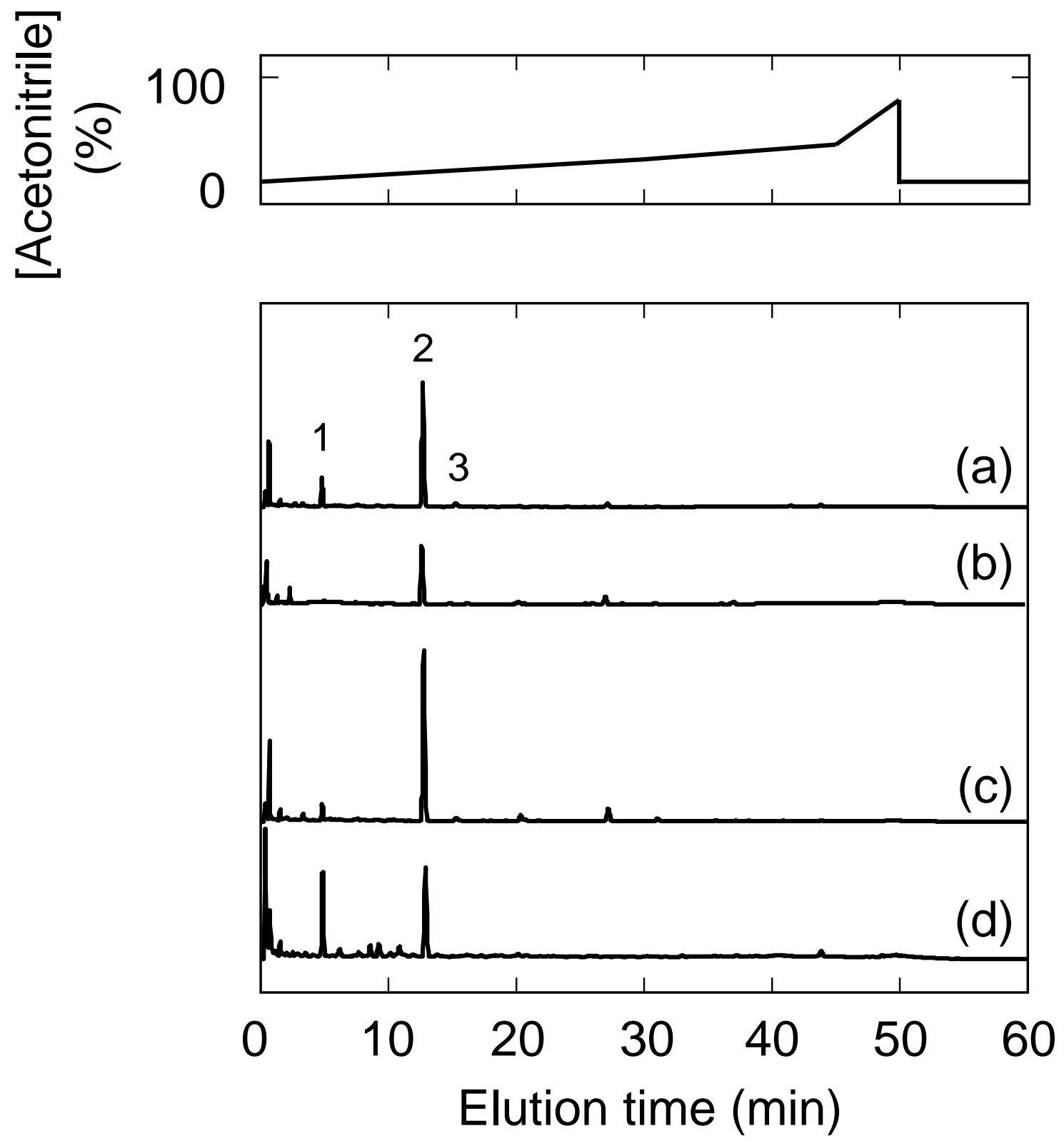

Fig. 1 


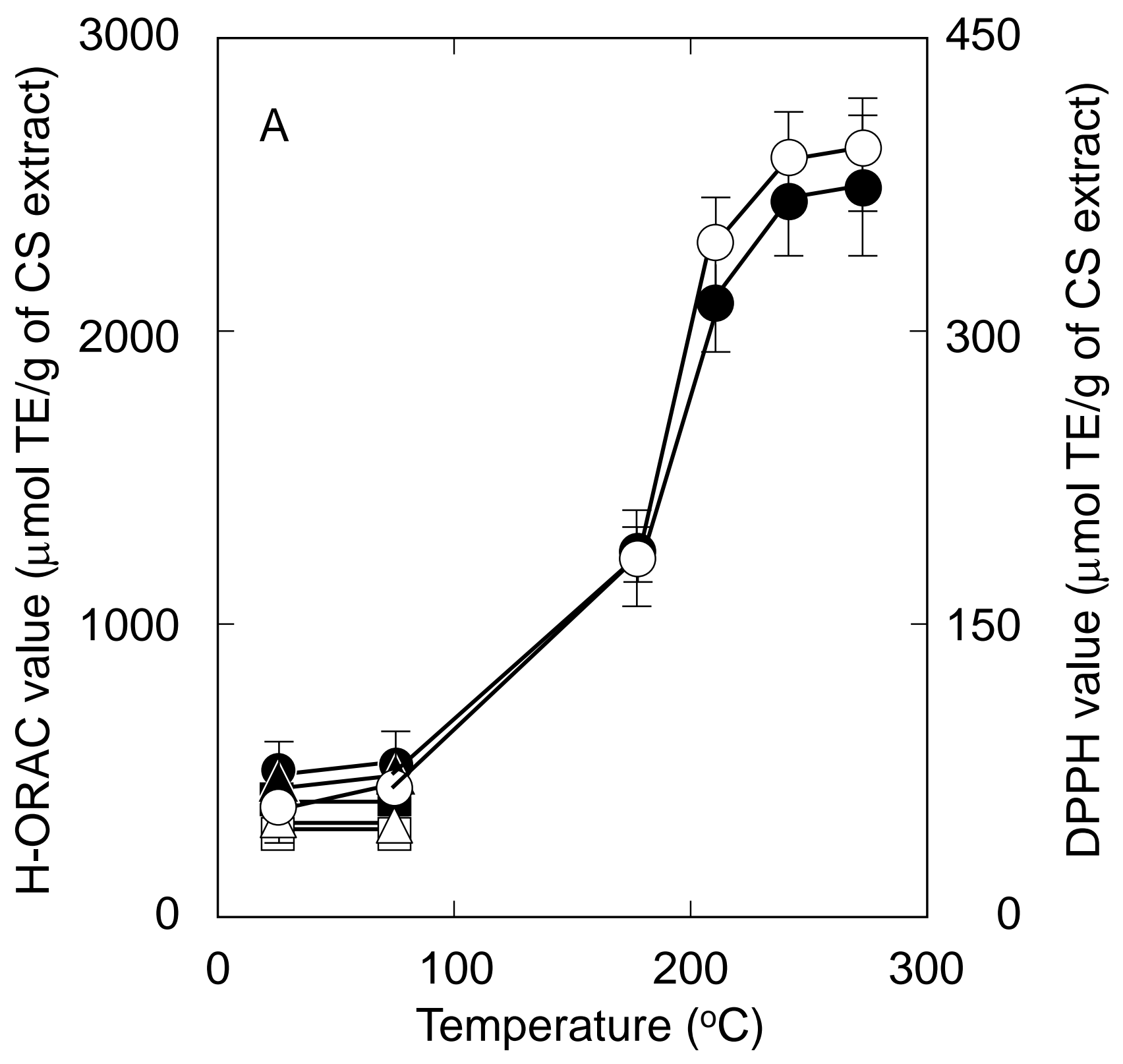

Fig. 2A 


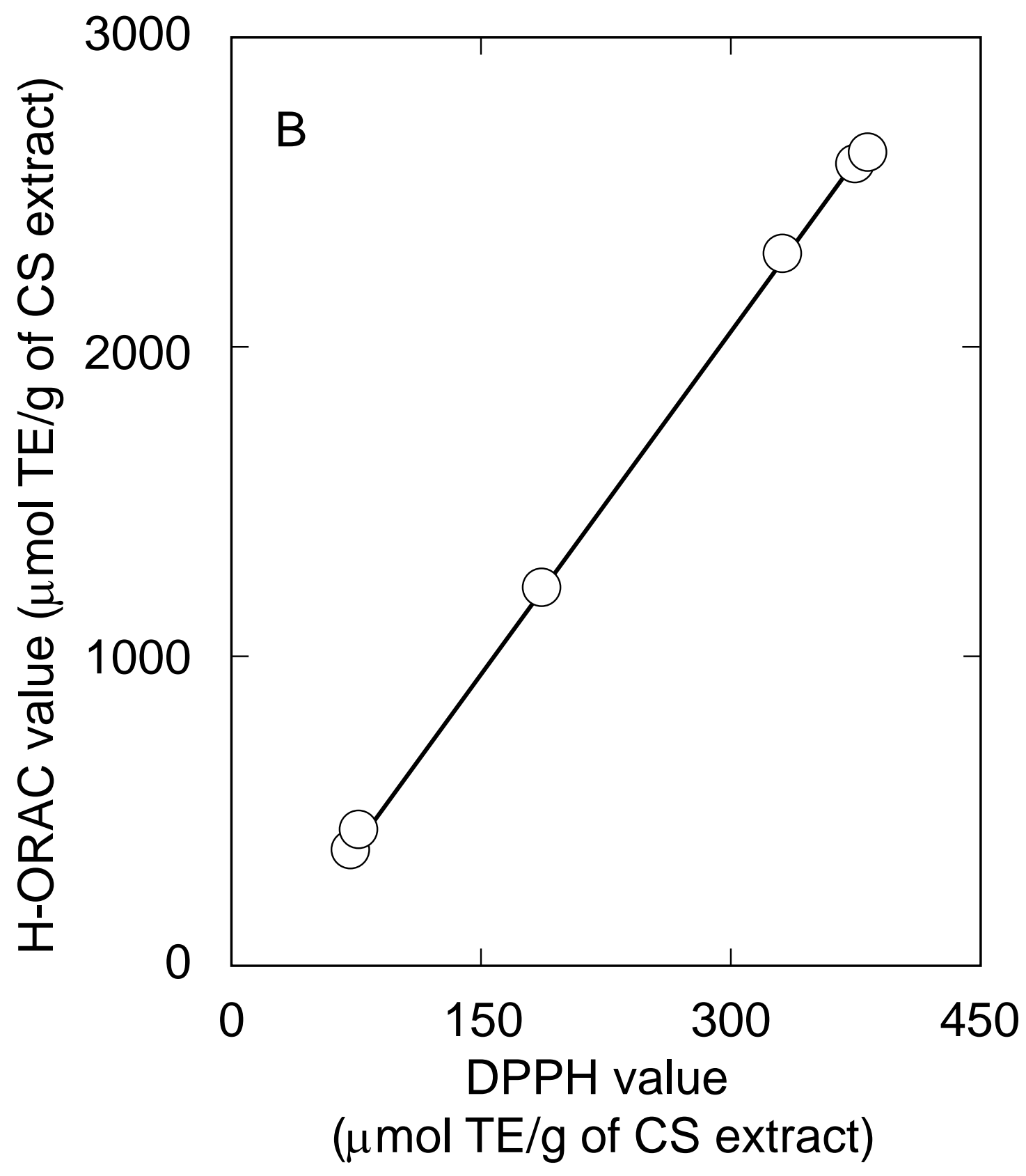

Fig. 2B 


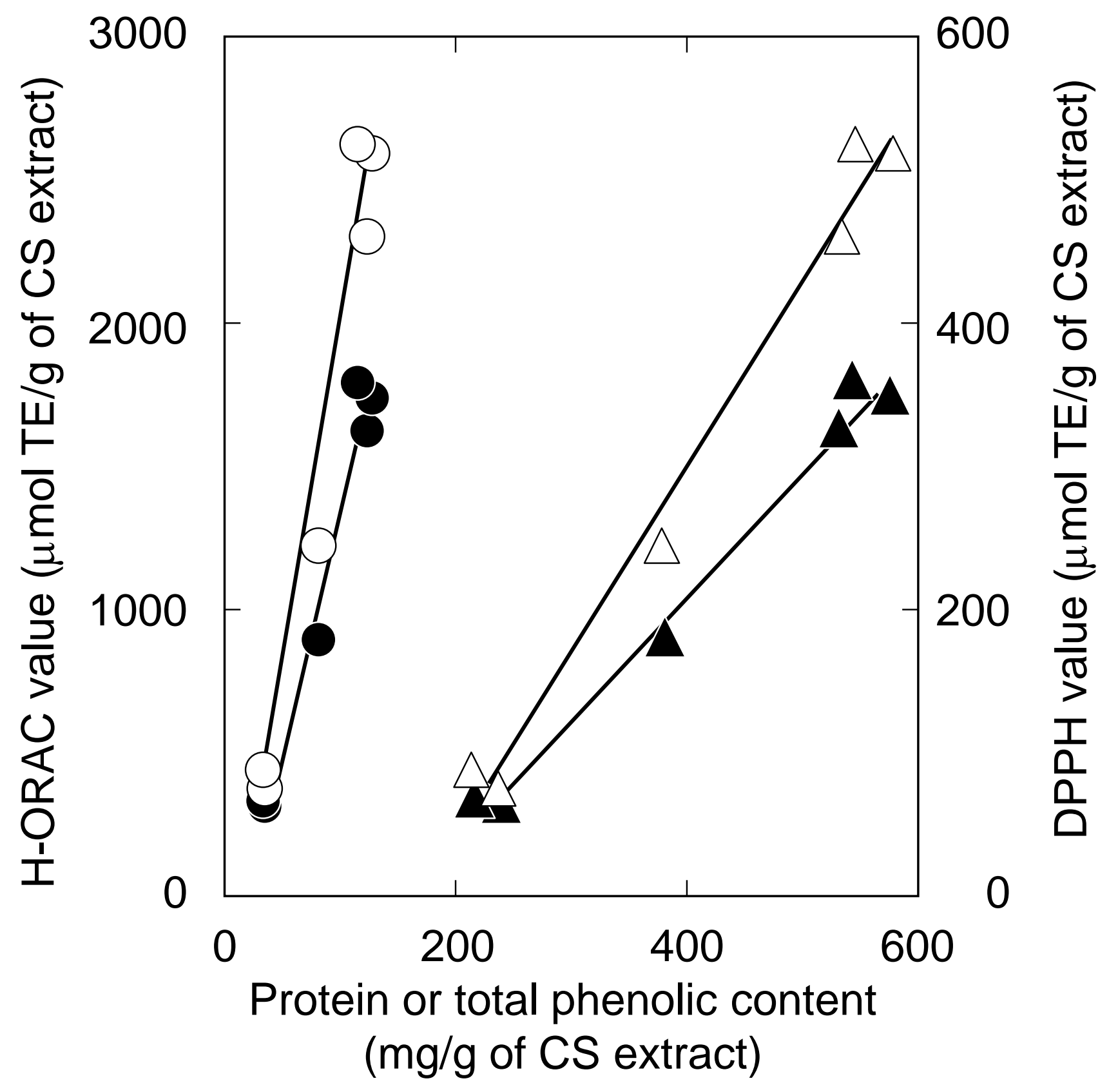

Fig. 3 